ECOLOGICA, Vol. 28, No 103 (2021), 443-450

https://doi.org/10.18485/ecologica.2021.28.103.15

Originalni naučni rad

UDC: $502.131 .1: 34$

\title{
Preventivna ekološka parnica kao poseban postupak građanskopravne zaštite životne sredine
}

\section{Preventive environmental litigation as a special procedure of civil environmental protection}

\author{
Dr Vladimir Crnjanski \\ Univerzitet Union, Pravni fakultet, Beograd, Srbija / \\ Union University, School of Law, Belgrade, Serbia \\ orcid.org/0000-0002-1434-6243 \\ e-mail: vladimir.crnjanski@pravnifakultet.rs
}

Rad primljen / Received: 10.12.2020, Rad prihvaćen / Accepted: 11.08.2021.

Sažetak: Prirodna sredina je ozbiljno narušena i zbog toga je obaveza očuvanja zdrave životne sredine od ključnog značaja. U integralnom pristupu zaštite životne sredine, preventivna ekološka parnica zauzima značajno mesto. Osnovni cilj preventivne ekološke parnice jeste sprečavanje nastanka štete po životnu sredinu. Postoji dovoljan broj opravdanih razloga koji ukazuju na potrebu da se de lege ferenda u Republici Srbiji potpunije uredi postupak sprečavanje nastanka opasnosti od štete većih razmera u odnosu na neodređen krug lica putem preventivne ekološke parnice. Zbog prostornog ograničenja u pogledu broja stranica, struktura rada ne obuhvata celokupan tematski osvrt već sadrži (prema mišljenju autora) najvažnija obeležja preventivne ekološke parnice kao posebnog postupka građanskopravne zaštite životne sredine.

Ključne reči: zdrava životna sredina, pravni značaj preventivne ekološke parnice u zaštiti životne sredine.

\begin{abstract}
The natural environment is seriously disturbed and therefore the obligation to preserve a healthy environment is crucial. In the integrated approach to environmental protection, preventive environmental litigation occupies an important place. The main aim of preventive environmental litigation is to prevent damage to the environment. There are a sufficient number of justified reasons that indicate the need to de lege ferenda in the Republic of Serbia more fully regulate the procedure of preventing the occurrence of danger of damage on a larger scale in relation to an indefinite circle of persons through preventive environmental litigation. Due to the spatial limitation in terms of the number of pages, the structure of the paper does not include the entire thematic review but contains (according to the author) the most important features of preventive environmental litigation as a special procedure of civil environmental protection.
\end{abstract}

Keywords: healthy environment, legal significance of preventive environmental litigation in environmental protection. 


\section{UVOD / INTRODUCTION}

Zdrava životna sredina jeste osnovni preduslov kvalitetnog života ljudi i očuvanja njihovog zdravlja. Pravo na zdravu životnu sredinu predstavlja jezgro osnovnih ljudskih prava i sloboda. Ustav Republike Srbije posebno i izričito propisuje pravo na zdravu životnu sredinu - svako ima pravo na zdravu životnu sredinu i na blagovremeno i potpuno obaveštavanje o njenom stanju. Pored toga, svako je dužan da čuva i poboljšava životnu sredinu i odgovoran je za zaštitu životne sredine, pri čemu je posebno propisana odgovornost za zaštitu životne sredine na strani Republike Srbije i autonomne pokrajine (Ustav Republike Srbije, čl. 74). Zakonom o zaštiti životne sredine (2004-2018) uređen je integralni sistem zaštite životne sredine kojim se obezbeđuje ostvarivanje prava čoveka na život i razvoj u zdravoj životnoj sredini i uravnotežen odnos privrednog razvoja i životne sredine u Republici Srbiji. Životnu sredinu čini skup prirodnih i stvorenih vrednosti čiji kompleksni međusobni odnosi predstavljaju okruženje, odnosno prostor i uslove za život (Zakon o zaštiti životne sredine, 2004-2018, čl. 3 , stav 1 , tačka 1). Pored jasno propisane odgovornosti zagađivača za štetu nanetu životnoj sredini $i$ prostoru, izričito je propisano da je postupak pred sudom za naknadu štete hitan (čl. 107, stav 5 Zakona o zaštiti životne sredine). Cilj ovoga rada jeste da se ukaže na pravni značaj preventivne ekološke parnice kao posebnog postupka građanskopravne zaštite životne sredine. $U$ radu se primenjuje uporednopravni metod naučnog istraživanja kao i dogmatički metod. Analizom pojedinih zakonskih rešenja primenom dogmatičkog metoda ukazaće se na nužne i potrebne izmene konkretnih zakonskih pravila u našem sistemu prava.

Pravo na zdravu životnu sredinu ima složenu unutrašnju strukturu i obuhvata materijalnopravne, organizacionopravne i procesnopravne norme koje uređuju njenu zaštitu. Pravo na zaštitu životne sredine predstavlja posebnu pravnu disciplinu koja se odlikuje osobenim konceptom pravnog uređenja, nestandardnim postupcima zaštite životne sredine i jedinstvenim pravnim subjektima (Proso, 2015). Konvencijom o građanskoj odgovornosti za štete nastale usled delatnosti opasnih po životnu sredinu (Convention on Civil Liability for Damage Resulting from Activities Dangerous to the Environment, 1993) prihvaćeno je načelo "zagađivač plaća". Shodno pomenutom načelu, za štetu nastalu zagađenjem životne sredine odgovara lice koje je preduzelo radnje koje su prouzrokovale zagađenje životne sredine. Pored pomenute Konvencije, ovom prilikom spomenućemo još i Konvenciju o dostupnosti informacija, učešću javnosti u donošenju odluka i pravu na pravnu zaštitu u pitanjima životne sredine (Arhuska konvencija)
(Convention on Access to information, 1998). U cilju potpunije primene Arhuske konvencije naknadno su donete i dve direktive: Direktiva 90/313 i Direktiva 2003/4. U njima je posebno naglašen značaj informisanja javnosti u pogledu zaštite životne sredine.

\section{PRAVNI ZNAČAJ PREVENTIVNE EKOLOŠKE PARNICE U ZAŠTITI ŽIVOTNE SREDINE I LEGAL SIGNIFICANCE OF PREVENTIVE ECOLOGICAL LITIGATION IN ENVIRONMENTAL PROTECTION}

Građanskopravna zaštita životne sredine ima dvostruki značaj. Pre svega, prventivnopravni koji ima za cilj sprečavanje nastanka štete. S druge strane, represivna priroda zaštite usmerena je na saniranje posledica nastalih zagađenjem zdrave životne sredine. Preventivna procesnopravna zaštita usmerena je na sprečavanje nastanka štete po zdravu životnu sredinu. Drugim rečima, pravni značaj preventivne građanskopravne zaštite ogleda se u zaštiti od ugrožavanja zdrave životne sredine. Preventivna procesnopravna zaštita radi sprečavanja nastanka štete po životnu sredinu ostvaruje se trima tužbama: tužbom zbog imisija, tužbom zbog smetanja državine i ekološkom tužbom. S obzirom na preventivnopravni aspekt zaštite, parnični postupak koji se pokreće preventivnom ekološkom tužbom predstavlja delotvorni postupak građanskopravne zaštite životne sredine (Proso, 2015).

\subsection{Pravna obeležja ekološke tužbe / Legal features of an environmental lawsuit}

$U$ našem pravnom sistemu zakonski osnov za ekološku tužbu jeste čl. 156 Zakona o obligacionim odnosima (1978-2020). Na osnovu čl. 156, stav 1 Zakona o obligacionim odnosima svako može zahtevati od drugog da ukloni izvor opasnosti od koga preti znatnija šteta njemu ili neodređenom broju lica, kao i da se uzdrži od delatnosti od koje proizilazi uznemiravanje ili opasnost od štete, ako se nastanak uznemiravanja ili štete ne može sprečiti odgovarajućim merama. Iz formulacije pomenutog člana proističe dilema da li aktivnu legitimaciju za podnošenje tužbe ima samo lice kome preti ekološka šteta ili tužbu može podneti i lice koje ne ulazi u krug "neodređenog broja lica" kojima šteta preti. Preovlađujući stav je da ekološku tužbu može podneti svako lice, dakle i ono lice kojem ne preti opasnost od štete (actio popularis) (Rakić Vodinelić, 1989).

Ekološka tužba je posebna tužba kojom svako može zahtevati od drugog da ukloni izvor opasnosti od kog preti znatnija šteta njemu ili drugom licu kao i da se uzdrži od delatnosti od koje proizilazi uznemiravanje ili opasnost od štete ukoliko se takve posledice ne mogu sprečiti na drugi način. Tužilac, dakle, može biti svako fizičko ili pravno lice pri čemu 
je parnični sud ovlašćen da prizna svojstvo stranke i onim oblicima koji nemaju stranačku sposobnost prema opštim pravilima parničnog postupka (ius standi in iudicio). Na taj način se proširuje krug lica koji mogu da zaštite životnu sredinu. Zbog tako proširenog opsega aktivne legitimacije - ekološka tužba ima značaj actio popularis. S druge strane, pasivnu legitimaciju ima bilo koje fizičko ili pravno lice koje obavlja delatnost koja predstavlja izvor opasnosti. Kako bi zaštita životne sredine bila potpunija, u ekološkim parnicama široko se tumači pojam lica koje je držalac izvora opasnosti. U slučaju sumnje, treba tumačiti in favorem objekta zaštite životne sredine. Shodno tome, svako lice koje bi u bilo kom pogledu moglo da se dovode u vezu sa izvorom opasnosti imalo bi tretman jedinstvenog suparničara (ne nužnog suparničarstva) (Šago, 2013). Kod ekološke tužbe postoje i određena procesnopravna ograničenja koja se odnose, pre svega, na određenost tužbenog zahteva. U skladu s opštim pravilima parničnog postupka, u tužbi se mora naznačiti tačan i potpun zahtev (uključujući i označenje mera za sprečavanje nastanka štete) i činjenični supstrat na kome se zasniva tužbeni zahtev. Kod preventivne ekološke parnice treba dokazati postojanje činjenica koje ukazuje na nastupanje opasnosti koja preti, pri čemu opasnost od štete mora biti konkretna i izvesna (ne može biti uslovljena budućom neizvesnom okolnošću). Osnovni pravozaštitni cilj ekološke tužbe jeste da spreči započinjanje delatnosti koja bi mogla da izazove štetne posledice po životnu okolinu. Nakon sprovedenog veštačenja i preciznijeg ukazivanja na adekvatne mere koje je potrebno odrediti da bi se sprečila opasnost po životnu sredinu, tužilac treba da uredi tužbu.Tužbeni zahtev mora da sadrži tačan i potpun zahtev, odnosno adekvatne mere za sprečavanje štete. Činjenično stanje na kom se zasniva tužba zavisi od toga da li je do štete već došlo ili postoji opasnost od nastanka štete. S tim u vezi, videti presudu Vrhovnog suda Hrvatske, Rev-1884/85 od 14. februara 1986. godine: „Obveza uklanjanja opasnosti od štete poduzimanjem društveno opravdanih mjera postoji već tada kad je izvjesna opasnost od nastanka štete, a ne tek nastupanjem štete" (Šago, 2013). Za štetu nastalu zagađenjem životne sredine odgovara fizičko ili pravno lice koje je prouzrokovalo zagađenje, kao i lice koje je nezakonitim ili nepravilnim delovanjem omogućilo ili dopustilo zagađenje životne sredine. Isto tako za štetu odgovara i svako lice čije je delovanje posredno ili neposredno prouzrokovalo zagađenje životne sredine. Preventivnopravna funkcija ekološke tužbe prvenstveno se ogleda u tome što se nametanjem određene obaveze tuženi sprečava i ograničava u pogledu mogućnosti prouzrokovanja štete zagađenjem zdrave životne sre- dine. Tužbeni zahtev mora da sadrži tačan i potpun zahtev, odnosno adekvatne mere za sprečavanje štete. Pored objektivne odgovornosti, postoji i odgovornost po osnovu dokazane krivice. U pitanju su situacije kada imitent obavlja delatnost koja se ne smatra opasnom delatnošću. Tada se zahteva od tužioca kao oštećenog da dokaže krivicu tuženog u pogledu mogućnosti nanošenja štete, čime se pozicija tužioca u znatnom pogledu otežava (Šago, 2013).

Preventivna ekološka parnica zasnovana je na preventivnoj ekološkoj tužbi koja ima dvostruki funkcionalni značaj: preventivni i posledični. Ekološka tužba se prvenstveno podnosi kada do štete još nije došlo (kako bi se sprečilo njeno nastupanje) i sadrži tužbeni zahtev da sud obaveže imitenta (tuženog) da o svom trošku primeni adekvatnu tehnološku meru koja sprečava nastupanje štete. Sledstveno tome, preventivna ekološka tužba podnosi se u situaciji kada šteta još nije nastupila i sadrži zahtev da se spreči njeno nastupanje. S druge strane, dozvoljeno je da se tužba podnose i kada je šteta već nastupila - kada je tužbeni zahtev usmeren na naknadu ukupne štete (materijalne i nematerijalne) (Salma, 2014). Tuženi je konkretni imalac (držalac) izvora koji predstavlja opasnost za nastupanje apstraktne štete za neodređeni krug lica. Tužilac može da bude svako lice čijem zdravlju ili imovini preti nastupanje štete usled imisione opasnosti. S tim u vezi, tužbu može da podnese svako zainteresovano lice (pa i ono kome ne preti opasnost od štete). Zaštita životne sredine je u interesu svih građana jer predstavlja zajedničku vrednost. Upravo je to jedan od najvažnijih razloga zbog kog ekološka tužba ima značaj actio popularis. Tužilac u tužbenom zahtevu traži da sud obaveže tuženog imitenta da preduzme potrebne preventivne mere podobne za sprečavanje nastupanja štete kao i da troškovi otklanjanja rizika od štete padnu na teret tuženog. Preventivne mere kojima se sprečava nastupanje štete mogu biti različite: ugradnja filtera za prečišćavanje vode, ugradnja zaštitnih filtera kojima se sprečava zagađenja vazduha, uklanjanje određenih materijala koji predstavljaju opasnost za zdravlje ljudi i sl. S obzirom na to da ova tužba ima i javnopravnu prirodu, razlikuje se od klasične tužbe koja se može podneti isključivo od strane lica koje tvrdi da mu je povređeno njegovo subjektivno pravo ili pravom zaštićen interes. Kod prethodnog ispitivanja preventivne ekološke tužbe, ne ispituje se opšta procesna pretpostavka postojanja pravnog interesa na strani tužioca jer je zakonom propisano da je zaštita životne sredine interes svih građana (Salma, 2014). Van svake sumnje, preventivna ekološka parnica predstavlja najadekvatniji oblik pravne zaštite jer sprečava dalje narušavanje zdrave životne sredine. Kod nje se primenjuje princip objektivne odgovornosti i dovoljno je 
da se dokaže verovatnoća nastupanja štete širih razmera (za širi krug ljudi), ili ukoliko je šteta već nastupila da se dokaže uzročna veza između nastale štete i imisione radnje ili propuštanja kada je zakonom propisana dužna pažnja na strani imitenta. Još jedna osobenost koja ima značaj materijalnopravnog uslova za podnošenje ove tužbe jeste da se s visokim stepenom verovatnoće može pretpostaviti da će šteta nastupiti ukoliko izostanu tužbom zahtevane preventivne mere. U pogledu uzročne veze između imisione radnje i eventualne posledice, nužno je dokazati da postoji izvor opasnosti iz kog može da nastupi šteta. Dovoljno je da se učini verovatnim da će nastupiti šteta širih razmera ukoliko sud ne odredi adekvatnu meru za sprečavanje njenog nastupanja. Krivica, po pravilu, nije uslov odgovornosti jer je ekološka šteta zasnovana na principu objektivne odgovornosti (čl. 103 Zakona o zaštiti životne sredine). Kako je u pitanju šteta koja preti većem broju lica, protivpravnost se pretpostavlja. Ukoliko se u parnici dokaže da preti šteta širih razmera neodređenom broju lica, nije potrebno posebno dokazivati postojanje protivpravnosti (zbog opšteg načela zabrane prouzrokovanja štete drugom). Dokazivanje protivpravnosti potrebno je samo u slučaju kada je zahtev za naknadu štete podnet nakon što je opasnost od štete već realizovana (ne i kada se radi o tužbi radi otklanjanja izvora opasnosti) (Salma, 2014).

U Hrvatskoj je dozvoljena mogućnost sudske zaštite kolektivnih interesa putem tužbe za zaštitu kolektivnih interesa i prava (čl. 502a Zakona o parničnom postupku, 1991-2019). Zaštita kolektivnih interesa i prava ostvaruje se podnošenjem tužbe nadležnom sudu. U postupku zaštite kolektivnih interesa i prava osnovni (opštinski) i privredni sudovi su stvarno nadležni da postupaju po preventivnoj ekološkoj parnici, dok je propisana izborna mesna nadležnost suda - sud opšte nadležnosti za tuženog ili sud na čijem području se nalazi mesto gde je izvršena radnja kojom je povređen kolektivni interes ili pravo radi čije zaštite je tužba i podnesena, osim ako posebnim propisom nije drukčije određeno. Aktivnu legitimaciju za podnošenje ove tužbe imaju samo određena pravna lica i nadležni organi. Pravno lice mora da ima registrovanu delatnost za zaštitu kolektivnih interesa i prava građana. Pasivno legitimisani u parnicama za zaštitu kolektivnih interesa i prava mogu biti fizička i pravna lica koja obavljaju određene delatnosti ili svojim radom, postupanjem (uključujući i propuštanjem) teže povređuju ili ozbiljno ugrožavaju zakonom zaštićene kolektivne interese i prava. U hrvatskom procesnom pravu fizičko lice nije ovlašćeno da podnose tužbu za zaštitu kolektivnih interesa i prava (nije prihvaćen sistem pravne zaštite class action koji se primenjuje u SAD). Fizičko lice zbog povređenih ili ugroženih svojih subjektivnih prava može da podnese tužbu u skladu sa opštim pravilima parnične procedure (Pavlović, 2015).

U parničnom postupku započetom tužbom za zaštitu kolektivnih interesa i prava mogu se s položajem jedinstvenog suparničara umešati na strani tužioca ( $i$ uz njegovu saglasnost) i drugi ovlašćeni podnosioci tužbe. Oni moraju da budu ovlašćeni za samostalno podnošenje tužbe za zaštitu kolektivnih interesa i prava, pri čemu se njihovo učešće u svojstvu umešača može ograničiti samo na neke od postavljenih zahteva. Pored toga, kao obični umešači mogu se pojaviti fizička i pravna lica radi zaštite čijih kolektivnih prava je tužba i podnesena. S tim u vezi, ukoliko bi više ovlašćenih lica za podnošenje tužbe za zaštitu kolektivnih interesa i prava podnelo veći broj tužbi pred istim ili različitim sudovima, sud pred kojim bi se zasnovala kasnija parnica zatražio bi od tužioca da dokaže svoj pravni interes za samostalno vođenje kasnije parnice. U ovakvim izuzetnim situacijama došlo bi do odstupanja od opšteg pravila da se kod preventivne ekološke tužbe ne ispituje opšta procesna pretpostavka postojanja pravnog interesa na strani tužioca. Shodno tome, postojanje pravnog interesa i odluka suda zavisiće od stava tužioca. Ako bi se raniji tužilac saglasio sa intervencijom, vođenje kasnije zasnovane parnice bilo bi nedopušteno. Nasuprot tome, ako bi se raniji tužilac usprotivio, „kasniji“ tužilac bi imao pravni interes. Konačno, ukoliko bi više ovlašćenih lica za podnošenje tužbe za zaštitu kolektivnih interesa i prava podnelo više takvih tužbi pred istim sudom, saglasno načelu ekonomičnosti postupka, moglo bi da dođe do zajedničkog raspravljanja (spajanjem postupaka) (Pavlović, 2015). Međutim, ne bi postojao pravni interes za vođenje bilo koje od parnica ukoliko bi bili postavljeni sadržajno „podudarni“ tužbeni zahtevi uz ispunjenje sledećih kumulativnih uslova: da u jednoj od parnica zahtev bude pravnosnažno usvojen i da je tužilac iz parnice koja nije pravnosnažno okončana ovlašćen na osnovu pravnosnažno usvajajuće presude da zahteva prinudno izvršenje (Dika, 2011).

Delotvornost kolektivne tužbe za zaštitu kolektivnih interesa i prava ostvaruje se usvajanjem tužbenog zahteva, dakle donošenjem presude kojom se tuženi obavezuje na trpljenje ili propuštanje. Sadržina i struktura tužbenog zahteva na trpljenje razlikuje se od sadržine tužbenog zahteva na propuštanje određenih radnji. Kada je u pitanju tužbeni zahtev koji sadrži činidbu usmerenu na trpljenje, tužilac bi trebalo da odredi pojedinačne mere koje je tuženi dužan da trpi, pri čemu ne treba bliže da označi radnje koje bi tuženi trebalo da propusti. Nasuprot tome, kod tužbe na propuštanje, tužilac treba u tužbenom zahtevu da naznači i odredi radnje propuštanja ili ponašanja koje 
bi tuženi bio dužan da izvrši (Triva, Dika, 2004). S tim u vezi, posebno treba ukazati na problem određenosti tužbenog zahteva u tužbama za propuštanje. Prvenstveno se to odnosi na određenost činidbe propuštanja, odnosno na proširenu mogućnost da se osim zabrane izričito određenih radnji zahteva i zabrana sličnih radnji kojima se suštinski na sličan način povređuje pravo tužioca. U prilog širem tumačenju idu razlozi pravne sigurnosti i opšta načela savesnosti i poštenja i zabrane prouzrokovanja štete drugom. $\mathrm{Na}$ taj način zabranjenim bi se smatrale ne samo radnje koje su izričito određene u izreci presude nego i one radnje kojima se na suštinski sličan način povređuju prava tužioca. Zabranjenim radnjama tuženog smatrale bi se ne samo radnje koje bi u izreci presude bile izričito navedene nego i one radnje kojima se u bitnom pogledu na podudaran način povređuje pravo tužioca ili trećih lica (nezavisno od toga da li su navedene u izreci presude) (Pavlović, 2015). Ilustrativan primer u tom pogledu je, recimo, situacija u kojoj je doneta presuda kojom se zabranjuje tuženom da bez prethodnog odsumporavanja ili preduzimanja sličnih tehničkih mera vrši imisiju sumpor-dioksida u životnu sredinu preko dozvoljenih graničnih vrednosti. U tom slučaju određena činidba na propuštanje obuhvatila bi ne samo odsumporavanje nego i preduzimanje sličnih tehničkih mera kojima bi se sprečila imisija sumpor-dioksida preko dozvoljenih graničnih vrednosti koje zagađuju životnu sredinu (iako druge tehničke mere nisu pojedinačno navedene $u$ izreci presude). Shodno tome, u izvršnom postupku pokrenutom na osnovu takve presude kojom se obavezuje izvršni dužnik (tuženi) na određeno propuštanje važilo bi pravilo proširene pravnosnažnosti u pogledu njene podobnosti za izvršenje.

\subsection{Dokazni postupak / Evidentiary proceedings}

Posebnost ekološke parnice ogleda se i u dokaznom postupku. $U$ dokazno pravo spadaju i zakonske norme koje propisuju određene zabrane ili ograničenja u dokaznom postupku utvrđivanja relevantih činjenica. U pravnoj nauci postoje sledeće dokazne zabrane: zabrane koje se odnose na predmet dokazivanja, zabrane koje se odnose na pojedina dokazna sredstva kao pravne instrumente dokazivanja određenih činjenica, zabrane koje se tiču načina izvođenja dokazivanja kao i zabrane koje se tiču postupka prihvatanja rezultata određenih izvedenih dokaza (RECHBERGER-SIMOTTA, 2009). Ovu opštu podelu trebalo bi proširiti i zabranom korišćenja određenih metoda prilikom procenjivanja dokazne snage izvedenih dokaza (Dika, 2016). Za predmet ovog rada od značaja je zabrana koja se odnosi na pojedina dokazna sredstva kao instrumenta dokazivanja određenih činjenica. Prema našem mišljenju, de lege ferenda u okviru posebnih pravila o preventivnoj ekološkoj par- nici treba voditi računa o ograničenom režimu dokaznih sredstava u postupku dokazivanja određenih činjenica. Ove vrste zabrana spadaju u relativne zabrane koje propisuju da se određene činjenice mogu dokazivati samo određenim dokaznim sredstvima (Dika, 2016).

Kada je u pitanju preventivna ekološka parnica moguća su dva pristupa. Prvi pristup sadrži „ublaženo" pravilo o zabrani dokazivanja spornih činjenica slično našem postojećem zakonskom uređenju dokaznog postupka u privrednim sporovima (sporne činjenice u privrednim sporovima se po pravilu dokazuju ispravama, čl. 484 Zakona o parničnom postupku (2011-2020)). Zakonska formulacija de lege ferenda mogla bi da glasi: „U ekološkim sporovima sporne činjenice o zaštiti životne sredine se po pravilu dokazuju veštačenjem. Veštačenje se određuje putem veštaka upisanog u registar sudskih veštaka u oblasti zaštite životne sredine." S tim u vezi, potrebno bi bilo de lege ferenda propisati i posebna zakonska pravila o dokaznom značaju veštačenja kao i posebne zakonske uslove u pogledu stručnih kvalifikacija veštaka kao prethodnom uslovu za njihov upis u registar veštaka u oblasti zaštite životne sredine. Drugo rešenje ima značaj relativne zabrane jer isključuje mogućnost utvrđivanja izvesnih činjenica u preventivnim ekološkim parnicama drugim dokaznim sredstvima osim veštačenjem. Strože pravilo koje bi predstavljalo klasičan primer relativne zabrane moglo bi da bude formulisano na sledeći način: „U ekološkim sporovima sporne činjenice o zaštiti životne sredine ne mogu se utvrđivati drugim dokaznim sredstvima osim veštačenjem. Veštačenje se određuje putem veštaka upisanog u registar sudskih veštaka u oblasti zaštite životne sredine." Zbog složenosti i značaja veštačenja u preventivnim ekološkim parnicama, zalažemo se da se de lege ferenda uvede jasno propisano ograničenje koje ima značaj relativne zabrane (Crnjanski, Gašić, 2020).

Kao što je ranije napomenuto, u preventivnoj ekološkoj parnici tužilac je dužan da u dokaznom postupku dokaže da bi bez naloženih sudskih preventivnih mera imisiono dejstvo izvesno nastupilo. Istovremeno, tužilac je dužan da dokaže i da je štetno dejstvo imisione pretnje usmereno prema neodređenom broju ljudi, odnosno da preti šteta širih razmera (Salma, 2014). Kod preventivne ekološke parnice teret dokazivanja, po pravilu, je na strani tužioca. Postupak dokazivanja je veoma složen iako važi opšti princip da "zagađivač plaća" (čl. 103 Zakona o zaštiti životne sredine). Delikatnost dokaznog postupka je dodatno naglašena i zbog činjenice da nastupanje štete može biti posledica nekih drugih faktora a ne samo inicijalne imisione radnje. Ukoliko se dokaže da šteta može da nastupi i usled nekih drugih razloga, nosilac inicijalne imisione radnje oslobađa se odgo- 
vornosti. Postupak dokazivanja otežava i činjenica da neretko postoji ozbiljan vremenski raskorak između pretnje štetom i nastupanja štetnih posledica širih razmera. Izuzetno, ukoliko je u dokaznom postupku dokazni predmet činjenica da šteta ne prelazi uobičajene (normalne) granice prilikom vršenja opštekorisne delatnosti za čije obavljanje je tuženi dobio dozvolu nadležnog organa, teret dokazivanja je na strani tuženog. Ukoliko je šteta nastala u obavljanju opšte korisne delatnosti za koju je dobijena dozvola nadležnog organa, na osnovu čl. 156, stav 3 Zakona o obligacionim odnosima može se zahtevati samo naknada štete koja prelazi normalne granice. Da li je šteta prešla uobičajene granice procenjuje se posebno za svaki konkreta slučaj (u pitanju je pravni standard koji se procenjuje posebno u svakoj parnici). S tim u vezi, pogledati deo presude Vrhovnog suda Srbije, Rev. 434/2001, od 6. februara 2002. godine: "Uobičajenu - normalnu štetu zbog izvođenja građevinskih radova na uređenju ulica tuženi nije dužan da nadoknadi tužiocu, več samo onu štetu koja prelazi normalne granice a koja je nastala ukoliko tuženi pri izvođenju radova nije preduzeo odgovarajuće potrebne mere da do štete ne dođe, odnosno da ona bude manja" (Salma, 2014).

\subsection{Prošireno dejstvo subjektivne pravnosnažnosti presude / \\ Extended effect of the subjective finality of the judgment}

Postoje određeni procesni nedostaci koji utiču na delotvornost ekološke tužbe. Sudske presude kod preventivne ekološke parnice mogu biti usvajajuće ili odbijajuće, u zavisnosti od uspešnosti postupka dokazivanja materijalnopravnih uslova. Recimo, ukoliko sud usvoji u celosti tužbeni zahtev i obaveže tuženog da preduzme adekvatne mere radi uklanjanja izvora opasnosti, otvara se problem aktivne legitimacije za pokretanje postupka prinudnog izvršenja činidbe određene pravnosnažnom presudom. Saglasno postojećim procesnim pravilima, presuda obavezuje stranke u postupku. Međutim, ratio legis zakonskog pravila ukazuje da ekološku tužbu može da podnese svako lice, pa u tom smislu svako bi mogao i da traži prinudno izvršenje činidbe (Rakić Vodinelić, 1989). Dodatno se pomenuta situacija može problematizovati ukoliko bi tužbeni zahtev bio u celosti odbijen. U tom slučaju bi se pojavila dilema da li odbijajuća presuda vezuje i lica koja ne spadaju u neodređen krug lica kojima preti opasnost od štete a nisu učestvovala u postupku. Zbog posebnog značaja zaštite životne sredine koje je ustavom utvrđeno pravo čoveka (jer predstavlja opšti interes), pravednije i pravno logičnije rešenje bilo bi da se i drugim licima (koja nisu učestvovala u parnici) dozvoli da pokrenu postupak protiv istog tuženog i sa istim tužbenim zahtevom ukoliko učine verovatnim da je prethodni tužilac nedovoljno pažljivo vodio spor (tada bi na tuženom bio teret dokazivanja da je prethodni spor vođen valjano) (Rakić Vodinelić, 1989).

Od vrste presude koja se donese povodom tužbe za zaštitu kolektivnih interesa i prava zavisiće i mogućnost da se u posebnim parnicama za naknadu štete fizička i pravna lica pozovu na pravno utvrđenje iz presude kojom su usvojeni zahtevi iz tužbe za zaštitu kolektivnih interesa i prava. U pitanju su pravila koja čine sastavni deo pravnog režima proširenog dejstva subjektivnih granica pravnosnažnosti presude. Prošireno dejstvo subjektivne pravnosnažnosti presude primenjuje se samo u slučaju da pojedini tužbeni zahtevi u korist fizičkih i pravnih lica čija je prava i interese tužilac štitio budu od strane suda i usvojeni. Shodno tome, fizička i pravna lica mogu da se pozovu samo na one presude kojima je izrečena određena zabrana ili naloženo određeno činjenje ukoliko bi se te zabrane ili činjenja suštinski „poklapale" s njihovim zahtevima. Dakle, radi se o ograničenom režimu proširenog dejstva subjektivne pravnosnažnosti odluke jer se primenjuje samo na presude koje su nepovoljne za tuženog. Fizička i pravna lica u svojim parnicama za naknadu štete moći će da se pozovu na utvrđenje da su određenim ponašanjem ili propuštanjem tuženog povređeni ili ugroženi zakonom zaštićeni kolektivni interesi i prava lica koje je tužilac ovlašćen da štiti (odluke o usvajanju zahteva za utvrđenje povrede ili ugrožavanja zaštićenih prava). Pored toga, moći će da se pozovu i na presude kojima su usvojeni zahtevi za izricanje određenih mera ili zabrana, ukoliko se te zabrane ili mere suštinski ne razlikuju od onih koje tužioci svojim tužbama žele da zaštite. U kasnijim odštetnim parnicama sud je vezan za prethodno pravnosnažno sudsko utvrđenje o postojanju povrede kolektivnog interesa i prava. Usled toga, sud nije ovlašćen da naknadno utvrdi da nema protivpravnosti ili odštetne odgovornosti tuženog i da se subjektivne granice pravnosnažnosti presude kojom je utvrđena povreda kolektivnih interesa i prava u ranijoj parnici ne protežu i na lica čija je prava tužilac štitio. Zbog specifičnosti zaštite kolektivnih interesa i prava i njihovog opšteg značaja, sud može da odluči da žalba ne zadržava izvršenje presude kojom je usvojen zahtev iz tužbe za zaštitu kolektivnih interesa i prava (Pavlović, 2015). Postoje dovoljno jasni pravni razlozi koji ukazuju da bi i kod nas trebalo de lege ferenda urediti poseban građanski postupak zaštite kolektivnih prava i interesa. Naravno, mnogo preciznije nego što je to bilo u formi pokušaja 2011. godine, koji je kritikovan od strane stručne javnosti. Konačno, određeni delovi tadašnjeg predloga zakonskih izmena od strane Ustavnog suda ocenjeni su kao nedopustivi za 
jedan zakonski tekst i suprotni Ustavu Republike Srbije. Uzimajući u obzir iznete primedbe, potrebno je ponovo formulisati jasan i sa stanovišta pravne sigurnosti kvalitetan predlog novog uređenja posebnog parničnog postupka za zaštitu kolektivnih interesa. Prvenstveno, nužno je preciznije odrediti pojam kolektivnih prava i interesa (videti Odluku Ustavnog suda Srbije, luz-51/2012) (Rakić Vodinelić, 2011).

Uzimajući u obzir navedene posebnosti preventivne ekološke parnice, postoji više nego dovoljan broj doktrinarnih razloga koji opravdavaju nestandardnost postupka preventivne ekološke parnice $\mathrm{i}$ potrebu njenog de lege ferenda posebnog uređenja. Pravila opšteg parničnog postupka uređuju postupak rešavanja standardnih modela sporova u imovinskopravnim odnosima. Međutim, ukoliko određeni sporovi zbog svojih posebnih obeležja odstupaju od klasičnih modela, postoji opravdan razlog da se na drugačiji i poseban način u odnosu na norme opšteg parničnog postupka uredi postupak njihovog rešavanja (Poznić i dr,. 2015). Preventivna ekološka parnica odlikuje se razlozima koji upućuju na posebnu hitnost u rešavanju spora zbog javnopravnog značaja zaštićenog dobra - zaštite životne sredine. Pored toga, kod preventivne ekološke parnice postoje i posebne materijalnopravne specifičnosti predmeta spora (recimo, ukoliko izvor opasnosti od štete nastaje prilikom obavljanja opštekorisne delatnosti za koju postoji odobrenje nadležnog organa pojavljuje se delikatno pitanje određenja prekomerne štete) i posebna pravila o aktivnoj legitimaciji za podnošenje preventivne ekološke tužbe kao i pravila o posebnom svojstvu stranaka (jedinstveni umešači i obični umešaći) koja zahtevaju i dodatnu specijalizaciju suda

\section{ZAKLJUČAK / CONCLUSION}

Pravo na zdravu životnu sredinu jeste od esencijalnog značaja za savremeno zakonodavstvo. U pitanju je osnovno ljudsko pravo i zbog toga zahtev da se u Republici Srbiji uredi poseban postupak preventivne ekološke parnice ima i svoje humanističko opravdanje. Svako fizičko lice može da podnese ekološku tužbu. Uz postojećeg tužioca i na njegovoj strani u preventivnoj ekološkoj parnici mogu se umešati kao jedinstveni suparničari i određena pravna lica i nadležni oragani uz ispunjenje dva uslova: da su sami ovlašćeni za podnošenje tužbe i da mogu samostalno podneti takvu tužbu. Kao obični umešači mogu se pojaviti i druga fizička i pravna lica čiji se interesi štite podnetom tužbom za zaštitu kolektivnih interesa i prava. Osnovni smisao i pravozaštitni cilj preventivne ekološke tužbe jeste da se spreči nastupanje štete u slučaju da šteta preti neodređenom krugu lica. Preventivnopravna zaštita proteže se na veći broj štetom ugroženih lica i zbog toga preven- tivna ekološka parnica ima i javnopravno obeležje. Ukoliko se zakonodavac odluči da uvede nov institut u našu parničnu proceduru, to bi zahtevalo i dodatno osposobljavanje ne samo sudija nego i drugih učesnika u postupku preventivne ekološke parnice, posebno veštaka. Zbog toga je nužno da uporedo nastanu promene i u drugim zakonskim propisima.

Parnica radi zaštite kolektivnih interesa i prava svoju delotvornost ostvaruje ukoliko pozitivnim posledicama utiče i na fizička i pravna lica čija se prava štite u takvoj parnici. Upravo zbog toga treba de lege ferenda proširiti dejstvo subjektivne pravnosnažnosti presude i na fizička i pravna lica koja naknadno pokrenu parnicu za naknadu štete kako bi se i oni mogli pozvati na utvrđenje iz pravnosnažne presude kojom je usvojen zahtev iz tužbe za zaštitu kolektivnih interesa i prava. Novo zakonsko uređenje mora da sadrži jasna pravila o aktivnoj legitimaciji, dokaznom značaju veštačenja i posebna pravila o proširenom dejstvu subjektivne pravnosnažnosti presude kojom je usvojen tužbeni zahtev za zaštitu kolektivnih interesa i prava.

Specifikum preventivne ekološke parnice je višeslojan. Pre svega, tiče se ovlašćenja za podnošenje tužbe, nestandardnim pravilama uređenja jedinstvenih i običnih umešača, značaju veštačenja u dokaznom postupku, hitnosti postupka, proširenom dejstvu subjektivne pravnosnažnosti usvajajuće presude i, s tim u vezi, stvarne legitimacije za pokretanje postupka prinudnog izvršenja. Zbog svega navedenog, postoji više nego dovoljan broj pravno utemeljenih razloga da se u Republici Srbiji de lege ferenda uredi poseban građanskosudski postupak zaštite kolektivnih interesa i prava koji bi uključivao i posebna pravila o uređenju preventivne ekološke parnice.

\section{LITERATURA / REFERENCES}

[1] Convention on Access to information, Publish Participation in Decision-Making and Access to Justice in environmental Matters, 1998 (http://www.unece.org/env/pp/treatytext.htm).

[2] Convention on Civil Liability for Damage Resulting from Activities Dangerous to the Environment, CETS No. 150, Lugano, 21. jun 1993.

[3] Crnjanski, V., Gašić, D. (2020), Posebnost preventivne ekološke parnice, Zbornik apstrakata, Beograd, str. 212-214.

[4] Dika, M. (2011), Postupak u sporovima za zaštitu kolektivnih interesa i prava, Novela Zakona o parničnom postupku iz 2011. godine, Novi informator, Zagreb, 2011, str. 4. 
[5] Dika, M. (2016), O nedopuštenim dokazima u parničnom postupku, Zbornik Pravnog fakulteta Sveučilišta u Rijeci, 37(1), str. 4.

[6] Pavlović, M. (2015), Značaj tužbe za zaštitu kolektivnih interesa i prava, Zbornik radova Pravnog fakulteta u Splitu, 52(3), str. 802-816.

[7] Poznić, B., Rakić Vodinelić, V. (2015), Građansko procesno pravo, Sedamnaesto dopunjeno i izmenjeno izdanje, Beograd, str. 527-528.

[8] Proso, M. (2015), Građanskopravna odgovornost u području zaštite okoliša, Zbornik radova Pravnog fakulteta u Splitu, 52(3), str. 705-712.

[9] Rakić Vodinelić, V. (1989), Ekološka tužba: član 156. Zakona o obligacionim odnosima, Pravni život, 4/5, str. 874-884.

[10] Rakić Vodinelić, V. (2011), Zakon o parničnom postupku Srbije 2011, Pravni zapisi, 2/2011, str. 557.

[11] RECHBERGER-SIMOTTA, (2009). Zivilprozessrecht, Erkenntnisverfahren, 7. Izdanje, 2009, str. 401-403.

[12] Salma, M. (2014), Preventivna tužba za otklanjanje izvora opasnosti od štete u svetlu održivog razvoja, Zbornik radova Pravnog fakulteta u Novom Sadu, br. 4/2014, str. 134-143.
[13] Šago, D. (2013), Ekološka tužba kao instrument građanskopravne zaštite okoliša, Zbornik radova Pravnog fakulteta u Splitu, 50(4), str. 902-909.

[14] Triva, S., Dika, M. (2004), Građansko parnično procesno pravo, Narodne novine, Zagreb, 2004, str. 394-410.

[15] Ustav Republike Srbije, (2006), Službeni glasnik RS, br. 98/2006.

[16] Zakon o obligacionim odnosima, SI. list SFRJ, br. 29/78, 39/85, 45/89 - odluka USJ i 57/89, Sl. list SRJ, br. 31/93, SI. list SCG, br. 1/2003- Ustavna povelja i SI. glasnik RS, br. 18/20.

[17] Zakon o parničnom postupku, Narodne novine, br. 53/91, 91/92, 58/93, 112/99, 88/01, 117/03, 88/05, 2/07, 84/08, 96/08, 123/08, 57/11, 148/11, 25/13, 89/14, 70/19.

[18] Zakon o parničnom postupku, SI. glasnik RS, br. 72/11, 49/13- odluka US, 74/13- odluka US, $55 / 14,87 / 18,18 / 20$.

[19] Zakon o zaštiti životne sredine, Službeni glasnik RS, br. 135/2004, 36/2009, 36/2009- drugi zakoni, 72/2009-drugi zakoni, 43/2011 - odluka US, 14/2016, 76/2018, 95/2018- drugi zakoni i 95/2018- drugi zakoni. 